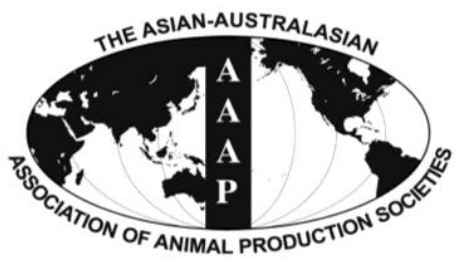

Asian-Aust. J. Anim. Sci.

Vol. 26, No. 4 : 573-578 April 2013

http://dx.doi.org/10.5713/ajas.2012.12544

www.ajas.info

pISSN 101 1-2367 elSSN 1976-5517

\title{
Evaluation of Bacteriophage Supplementation on Growth Performance, Blood Characteristics, Relative Organ Weight, Breast Muscle Characteristics and Excreta Microbial Shedding in Broilers
}

\author{
J. P. Wang, L. Yan, J. H. Lee ${ }^{1}$ and I. H. Kim* \\ Department of Animal Resource and Science, Dankook University, Cheonan, Choongnam, 330-714, Korea
}

\begin{abstract}
A total of 720 1-d-old male broilers (Arbor Acres) with the initial BW $=45 \pm 2 \mathrm{~g}$ were used in a 32-d experiment. Birds were randomly allotted into 1 of 4 treatments according to a completely random block design. Dietary treatments included: i) CON (basal diet), ii) ANT (CON+0.5 g antibiotics $/ \mathrm{kg}$ feed (bacitracin methylene disalicylate)), iii) BP1 (CON+0.25 bacteriophage $/ \mathrm{kg}$ feed), and iv) BP2 (CON+0.5 g bacteriophage/kg feed). The BWG and FI were not affected by dietary treatments throughout the whole experiment, whereas BP2 treatment reduced $(\mathrm{p}<0.05)$ the feed conversion ratio compared with the CON treatment during 0 to $14 \mathrm{~d}$. The birds fed bacteriophages at the level of $0.25 \mathrm{~g} / \mathrm{kg}$ increased $(\mathrm{p}<0.05)$ the relative liver weight. The inclusion of antibiotic and bacteriophage significantly reduced $(\mathrm{p}<0.05)$ the Escherichia coli and Salmonella concentration in the excreta compared with the NC group. Broilers fed the BP2 treatment had higher ( $\mathrm{p}<0.05)$ lactobacillus counts compared with those fed $\mathrm{NC}$ and PC treatments. In conclusion, dietary supplementation of $0.5 \mathrm{~g} / \mathrm{kg}$ bacteriophages increased feed efficiency and liver weight without effects on the breast muscle properties; also pathogens were inhibited by addition of bacteriophages. (Key Words: Bacteriophage, Broilers, Growth Performance, Microbiota, Organ Weight)
\end{abstract}

\section{INTRODUCTION}

The remaining economic and public health importance of Salmonella infection related to consumption of poultry products highlights a need for Salmonella control. Using feed additives to beneficially effect both performance and Salmonella colonization in broilers would be of interest to the poultry industry and be an important tool to control Salmonella in broilers (Eackhaut et al., 2008).

Bacteriophages are viruses that can infect and multiply in bacteria, and have been used to both prevent and treat bacterial diseases, making them an attractive alternative to antibiotics. Generally, bactieriophages are obligate intracellular parasites that multiply inside bacteria by making use of some or all of the host biosynthetic machinery. Once a phage enters into a bacterial cell, it starts replicating to 30 to 50 copies, causing the bacterium to disintegrate. Previous studies had reported the inclusion of

\footnotetext{
* Corresponding Author: In Ho Kim. Tel: +82-41-550-3652, Fax: +82-41-565-2949, E-mail: inhokim@ dankook.ac.kr

${ }^{1}$ CTC Bio., Seoul, Korea.

Submitted Oct. 3, 2012; Accepted Dec. 18, 2012; Revised Dec. 27, 2012
}

bacteriophages could successfully reduce the Salmonella $(S$.) counts in chicken internal organs and feces (Toro et al., 2005) or poultry products (Whichard et al., 2003; Huff et al., 2010). Atterbury et al. (2007) also evaluated three broad host range phages against $S$. enteritidis, S. Typhimurium and $S$. Hadar as a pre-harvest treatment in broilers chickens, and suggested that high phages was potentially effective to reduce the levels of Salmonella colonization in broilers. Recently, our previous study reported that the inclusion of bacteriophages could also benefit the laying hens in egg production and egg quality (Zhao et al., 2012). However, most of those previous studies were conducted under bacterial challenge condition, limited research have been conducted under normal physiological state. Thus, we want to know if the inclusion of bacteriophages alone could exert beneficial effect on Salmonella control and growth performance of broilers without bacterial challenge.

Collectively, the objective of the present study was to evaluate the effects of bacteriophages on growth performance, blood characteristics, relative organ weight, and breast muscle quality and excreta microbial in broiler chicken. 


\section{MATERIAL AND METHODS}

The experimental protocol was approved by the Animal Care and Use Committee of Dankook University.

\section{Experimental design, animals and diets}

Bacteriophages used in our study contain Salmonella (S.) gallinarum, S. typhimurium, and $S$. Enteritidis at the ratio of 3:3:4. The concentration of bacteriophages is $10^{8}$ plaque forming unit per gram. A total of 720 1-d-old male broilers (Arbor Acres) were used in a 32-d experiment. Birds were randomly allotted to 1 of 4 treatments in a completely random block design. The bacteriophage was administrated by replacing the same amount of corn. Each dietary treatment consisted of 12 replicate cages, with 15 broilers per replicate. Dietary treatments included: i) $\mathrm{CON}$ (basal diet), ii) ANT (CON+0.5 g antibiotics $/ \mathrm{kg}$ feed (bacitracin methylene disalicylate)), iii) BP1 (CON+0.25 bacteriophage $/ \mathrm{kg}$ feed), and iv) $\mathrm{BP} 2 \quad(\mathrm{CON}+0.5 \mathrm{~g}$ bacteriophage $/ \mathrm{kg}$ feed). All the chicks were kept in a battery brooder with three levels of stainless steel cages $(124 \mathrm{~cm}-$ width $\times 64-\mathrm{cm}$ length $\times 40$-cm height), with 8 adjacent cages per level. Each cage was equipped with 2 drinker nipples and 2 open trough feeders. The basal diet was formulated to meet or exceed all the nutrient requirements of broilers (NRC, 1994), and supplied in mash form. There were two nutritional phases, including starter ( 1 to $14 \mathrm{~d}$ ) and finisher phase (15 to $32 \mathrm{~d}$ ), and the ingredients and calculated nutrient composition of the basal diet are shown in Table 1. The temperature of the battery brooder was maintained at $33 \pm 1^{\circ} \mathrm{C}$ during the first week and decreased by $3^{\circ} \mathrm{C}$ per week until reaching $24^{\circ} \mathrm{C}$. Artificial light was provided 24 $\mathrm{h} / \mathrm{d}$ by the use of fluorescent lights. All diets were fed in mash form with feed and water being provided ad libitum throughout the experimental period.

\section{Sampling and measurements}

Broilers were weighed by pen and feed intake (FI) was recorded weekly. This information was then used to calculate $\mathrm{BW}$ gain $(\mathrm{BWG})$ and feed conversion ratio after correcting mortality (FCR).

On day $24 \mathrm{~d}$, broilers were fed the respective diets containing $0.20 \%$ chromic oxide $\left(\mathrm{Cr}_{2} \mathrm{O}_{3}\right)$ as an indigestible marker for $4 \mathrm{~d}$ prior to the collection period on $28 \mathrm{~d}$. The total excreta of the broilers were collected for $3 \mathrm{~d}$. All feed and fecal samples were immediately stored at $-20^{\circ} \mathrm{C}$ until analysis. The fecal samples were dried for $72 \mathrm{~h}$ at $70^{\circ} \mathrm{C}$ and finely ground to allow for passage through a $1-\mathrm{mm}$ screen. The procedures utilized for the determination of coefficient of total tract apparent digestibility for dry matter (DM), gross energy (GE) and nitrogen (N), in accordance with the methods established by the AOAC (2000). Chromium
Table 1. Feed composition (as-fed basis)

\begin{tabular}{|c|c|c|}
\hline Items & $\begin{array}{c}\text { Starter } \\
(1 \text { to } 14 \mathrm{~d})\end{array}$ & $\begin{array}{c}\text { Finisher } \\
(15 \text { to } 32 \mathrm{~d})\end{array}$ \\
\hline \multicolumn{3}{|l|}{ Ingredients $(\mathrm{g} / \mathrm{kg})$} \\
\hline Corn grain & 579.4 & 635.0 \\
\hline Corn gluten meal ( $61 \%$ crude protein) & 93.0 & 52.0 \\
\hline Soybean meal & 216.0 & 216.0 \\
\hline Fish meal ( $60 \%$ crude protein) & 41.8 & 27.0 \\
\hline Wheat bran & 4.0 & 4.0 \\
\hline Tallow & 36.7 & 37.3 \\
\hline Limestone & 16.0 & 16.0 \\
\hline Di-calcium phosphate & 5.0 & 4.5 \\
\hline L-lysine & 1.8 & 1.0 \\
\hline $\mathrm{NaCl}$ & 2.5 & 2.5 \\
\hline Vit.-Min. mixture ${ }^{1}$ & 2.5 & 2.5 \\
\hline Choline chloride $(25 \%)$ & 2.2 & 2.2 \\
\hline \multicolumn{3}{|l|}{ Analyzed composition } \\
\hline Metabolisable energy $^{2}(\mathrm{kcal} / \mathrm{kg})$ & 3,200 & 3,200 \\
\hline Crude protein $(\%)$ & 23.09 & 20.09 \\
\hline Lysine $(\%)$ & 1.21 & 1.05 \\
\hline Methionine $(\%)$ & 0.50 & 0.41 \\
\hline Calcium $(\%)$ & 1.02 & 0.93 \\
\hline Available phosphorus (\%) & 0.57 & 0.51 \\
\hline \multicolumn{3}{|c|}{$\begin{array}{l}{ }^{1} \text { Vit.-Min. mixture contains following amounts of micronutrients per kg: } \\
\text { Vitamin A, 1,600,000 IU; Vitamin } \mathrm{D}_{3}, 300,000 \mathrm{IU} \text {; Vitamin } \mathrm{K}_{3}, 130 \mathrm{mg} \text {; } \\
\text { Vitamin } \mathrm{B}_{2}, 1,000 \mathrm{mg} \text {; Niacin, 2,000 mg; Ca-Pantothenate, } 800 \mathrm{mg} \text {; } \\
\text { Folic acid, } 60 \mathrm{mg} \text {; DL-methionine, } 6,000 \mathrm{mg} \text {; Mn, } 12,000 \mathrm{mg} \text {; Zn, } 9,000 \\
\mathrm{mg} \text {; Fe, 4,000 mg; Cu, } 500 \mathrm{mg} \text {; I, } 250 \mathrm{mg} \text {; Co, } 100 \mathrm{mg} \text {; Ca, 7,140 mg; } \\
\text { BHT, 6,000 mg. }\end{array}$} \\
\hline
\end{tabular}

levels were determined via UV absorption spectrophotometry (UV-1201, Shimadzu, Kyoto, Japan) and the apparent total tract digestibility (ATTD) of DM, N, were calculated using indirect methods described by Williams et al. (1962). The gross energy was determined by measuring the heat of combustion in the samples using a Parr 6100 oxygen bomb calorimeter (Parr instrument Co., Moline, IL, USA).

On d 32, 24 broilers were randomly selected from each treatment ( 2 birds per cage) and blood samples were collected from the brachial vein into a sterile syringe. After collection, sample was aliquoted into both a vacuum (clot activator with gel) and $\mathrm{K}_{3}$ EDTA vacuum tube separately (Becton Dickinson Vacutainer Systems, Franklin Lakes, NJ, USA) and stored at $-4^{\circ} \mathrm{C}$. Samples for serum analysis were then centrifuged at $3,000 \times \mathrm{g}$ for $15 \mathrm{~min}$, and then separated and stored at $-4^{\circ} \mathrm{C}$. The white blood cells (WBC), red blood cells (RBC), and lymphocyte percentage were analyzed using an automatic blood analyser (ADVIA 120, Bayer, NY, USA).

After blood collection, the same broilers were weighed individually and killed by cervical dislocation and exsanguinated. The breast muscle (pectoralis major), bursa 
of Fabricius, liver, spleen, and abdominal fat were then removed by trained personnel and weighed. Organ weights were expressed as a relative percentage to the whole body weight. The breast muscle Hunter lightness $\left(\mathrm{L}^{*}\right)$, redness $\left(a^{*}\right)$, and yellowness $\left(b^{*}\right)$ values were determined using a Minolta CR410 chromameter (Konica Minolta Sensing Inc., Osaka, Japan). The $\mathrm{pH}$ of the breast muscle sample was measured by a calibrated, glass-electrode $\mathrm{pH}$ meter (WTW pH 340-A, WTH Measurement Systems Inc., Ft. Myers, FL, USA).

At d 32, excreta samples were collected from each pen and pooled and placed on ice for transportation to the laboratory, where analysis was immediately carried out. The composite fecal sample (1 g) from each pen was diluted with $9 \mathrm{ml}$ of $1 \%$ peptone broth (Becton, Dickinson and Co.) and homogenized. Viable counts of bacteria in the fecal samples were then determined by plating serial 10-fold dilutions (in $1 \%$ peptone solution) onto MacConkey agar plates (Difco Laboratories, Detroit, MI, USA) and lactobacilli medium III agar plates (Medium 638, DSMZ, Braunschweig, Germany) to isolate Escherichia coli (E. coli) and Lactobacillus, respectively. The lactobacilli medium III agar plates were then incubated for $48 \mathrm{~h}$ at $39^{\circ} \mathrm{C}$ under anaerobic conditions. The MacConkey agar plates were incubated for $24 \mathrm{~h}$ at $37^{\circ} \mathrm{C}$. Escherichia coli and Lactobacillus colonies were counted immediately after removal from the incubator. For Salmonella, the serially diluted peptone broth tubes were incubated overnight at $37^{\circ} \mathrm{C}$, after which $1 \mathrm{ml}$ was transferred to $9 \mathrm{ml}$ of tetratinate broth (Neogen Corporation, Lansing, MI, USA) and then incubated for $48 \mathrm{~h}$ at $42^{\circ} \mathrm{C}$. From these tubes, $1 \mathrm{ml}$ was used to inoculate $9 \mathrm{ml}$ of Rappaport Vassiliadis broth (Neogen Corporation, Lansing, MI, USA) and incubated for $48 \mathrm{~h}$ at $42^{\circ} \mathrm{C}$. The Rappaport was used to inoculate XLT4 plates for Salmonella isolation, and the Salmonella was, then, presumably identified using LIS and TSI agar tubes (Difco
Laboratories, Detroit, MI, USA).

\section{Statistical analyses}

Data were analyzed by ANOVA using the General Linear Models (GLM) procedure of SAS (SAS Institute, 1996), with the pen being defined as the experimental unit. Differences among treatments were separated by Duncan's multiple range test. The results were expressed as the least squares means and SE. Probability values less than 0.05 were considered significant.

\section{RESULTS}

\section{Growth performance and apparent total tract nutrient digestibility}

The inclusion of antibiotic and bacteriophages did not affect the BWG, FI and FCR during 15 to $32 \mathrm{~d}$ and overall experimental period (Table 2). However, dietary supplementation of $0.5 \mathrm{~g} / \mathrm{kg}$ bacteriophages reduced $(\mathrm{p}<0.05)$ the FCR compared with the CON treatment from $\mathrm{d}$ 1 to $14 \mathrm{~d}$.

No difference was observed in apparent total tract nutrient digestibility among treatments (Table 3 ).

\section{Blood characteristics}

Dietary antibiotic and bacteriophages supplementation diet did not affected RBC, WBC, lymphocyte percentage in the current study (Table 4).

\section{Meat color and organ weight}

Broilers fed the antibiotics and bacteriophage supplemental diet did not differ $(\mathrm{p}>0.05)$ in breast muscle color $\left(\mathrm{L}^{*}, \mathrm{a}^{*}\right.$ and $\left.\mathrm{b}^{*}\right)$ and $\mathrm{pH}$ value compared with those fed CON group (Table 5). However, the inclusion of bacteriophage at the level of $0.25 \mathrm{~g} / \mathrm{kg}$ increased $(\mathrm{p}<0.05)$ the relative liver weight to the body weight. No difference

Table 2. The effects of bacterophage supplementation on growth performance in broilers ${ }^{1}$

\begin{tabular}{|c|c|c|c|c|c|c|}
\hline Items & $\mathrm{CON}$ & ANT & BP1 & BP2 & $\mathrm{SE}^{2}$ & $\mathrm{p}$-value \\
\hline \multicolumn{7}{|l|}{1 to $14 \mathrm{~d}$} \\
\hline BWG, g & 326 & 325 & 335 & 345 & 13 & 0.08 \\
\hline FI, g & 498 & 479 & 483 & 490 & 27 & 0.55 \\
\hline FCR & $1.528^{\mathrm{a}}$ & $1.474^{\mathrm{ab}}$ & $1.442^{\mathrm{ab}}$ & $1.420^{\mathrm{b}}$ & 0.028 & 0.02 \\
\hline \multicolumn{7}{|l|}{15 to $32 \mathrm{~d}$} \\
\hline BWG, g & 1,085 & 1,085 & 1,083 & 1,083 & 12 & 0.35 \\
\hline FI, g & 1,710 & 1,692 & 1,718 & 1,691 & 20 & 0.21 \\
\hline FCR & 1.576 & 1.559 & 1.586 & 1.573 & 0.023 & 0.42 \\
\hline \multicolumn{7}{|l|}{1 to $32 \mathrm{~d}$} \\
\hline BWG, g & 1,410 & 1,409 & 1,418 & 1,427 & 14 & 0.22 \\
\hline FI, g & 2,208 & 2,171 & 2,202 & 2,181 & 23 & 0.54 \\
\hline FCR & 1.566 & 1.541 & 1.553 & 1.528 & 0.017 & 0.65 \\
\hline
\end{tabular}


Table 3. The effects of bacterophage supplementation on apparent coefficient of total tract nutrient digestibility (CTTAD) in broilers $^{1}$

\begin{tabular}{lcccccc}
\hline Items & CON & ANT & BP1 & BP2 & SE $^{2}$ & p-value \\
\hline Dry matter & 0.705 & 0.720 & 0.725 & 0.717 & 0.013 & 0.24 \\
Nitrogen & 0.541 & 0.555 & 0.550 & 0.560 & 0.025 & 0.41 \\
Gross energy & 0.649 & 0.663 & 0.653 & 0.655 & 0.012 & 0.22 \\
\hline
\end{tabular}

${ }^{1} \mathrm{NC}=$ Basal diet; $\mathrm{PC}=\mathrm{NC}+0.5 \mathrm{~g} / \mathrm{kg}$ antibiotics (bacitracin methylene disalicylate); $\mathrm{BP} 1=\mathrm{NC}+0.25 \mathrm{~g} / \mathrm{kg}$ bacterophage; $\mathrm{BP} 2=\mathrm{NC}+0.5 \mathrm{~g} / \mathrm{kg}$ bacterophage.

${ }^{2}$ Standard error.

was observed on the other relative organ weight among treatments.

\section{Excreta microbial shedding}

The inclusion of antibiotic and bacteriophage significantly reduced $(\mathrm{p}<0.05)$ the E. coli and Salmonella concentration compared with the CON group. Broilers fed the BP2 treatment led to a higher $(\mathrm{p}<0.05)$ lactobacillus concentration compared with those fed CON and ANT treatment.

\section{DISCUSSION}

In the current study, the effect of bacteriophage supplementation on the growth performance of broilers was investigated under normal physiological situation (without experimental Salmonella challenge). Results of our study suggested that the inclusion of antibiotics and bacteriophage did not affect the BWG, feed intake and nutrient digestibility throughout the experiment, which is partially in agreement with Huff et al. (2002), who suggested that the body weight were not affected by the inclusion of bacteriophage under normal physiological states. However, it should be noted that the improvement in feed efficiency
Table 5. The effects of bacterophage supplementation on blood profiles in broilers ${ }^{1}$

\begin{tabular}{|c|c|c|c|c|c|c|}
\hline Items & $\mathrm{CON}$ & $\overline{\text { ANT }}$ & $\overline{\mathrm{BP} 1}$ & $\overline{\mathrm{BP} 2}$ & $\overline{\mathrm{SE}^{2}}$ & $\overline{p \text {-value }}$ \\
\hline $\mathrm{RBC}\left(10^{6} / \mu \mathrm{l}\right)$ & 2.55 & 2.43 & 2.36 & 2.57 & 0.07 & 0.49 \\
\hline $\operatorname{WBC}\left(10^{3} / \mu \mathrm{l}\right)$ & 338 & 335 & 333 & 340 & 16 & 0.54 \\
\hline Lymphocyte $^{3}(\%)$ & 72.67 & 69.22 & 74.78 & 68.44 & 3.49 & 0.77 \\
\hline
\end{tabular}

was observed during starter phase (from d 1 to 14), and this effect diminished as age of chicks increased. And dietary bacteriophage at the levels of $0.25 \mathrm{~g} / \mathrm{kg}$ did not affect the growth performance in this study. The mechanism for bacteriophage improving feed efficiency only in starter phase is not well-documented. The addition of $0.5 \mathrm{~g} / \mathrm{kg}$ bacteriophage seems to have greater ADG than CON, although there is no statistical difference. This is likely because the younger chicks are more susceptible to pathogens and sensitive to the additives that can inhibit those potential pathogens in the environment. And the presence of bacteriophage enables the younger chicks to overcome potential pathogens that are not so detrimental to growing or finishing grower or finisher. In this way, it can work better in earlier age. Lack of response in nutrient digestibility may suggest that the bacteriophage may have no influence in nutrient digestion, which may need further experiment to confirm. Moreover, our study confirmed that higher levels of bacterophages is desirable to improve the feed efficiency, which is in agreement with Atterbury et al. (2007), who demonstrated that higher dosage of bacteriophage is desirable to maintain growth performance by reducing the $S$. enteritideis and S. Typhimurium in cecal content.

Table 4. The effects of bacterophage on meat color and relative organ weight in broilers ${ }^{1}$

\begin{tabular}{|c|c|c|c|c|c|c|}
\hline Items & $\mathrm{CON}$ & ANT & BP1 & $\mathrm{BP} 2$ & $\mathrm{SE}^{2}$ & $\mathrm{p}$-value \\
\hline \multicolumn{7}{|l|}{ Meat color } \\
\hline L* (Lightness) & 55.45 & 56.31 & 56.91 & 56.97 & 0.74 & 0.78 \\
\hline $\mathrm{a}^{*}$ (Redness) & 14.30 & 13.79 & 14.29 & 13.57 & 0.49 & 0.33 \\
\hline $\mathrm{b}^{*}$ (Yellowness) & 13.33 & 13.70 & 14.85 & 13.90 & 0.60 & 0.69 \\
\hline $\mathrm{pH}$ & 5.83 & 5.78 & 5.66 & 5.77 & 5.81 & 0.22 \\
\hline \multicolumn{7}{|c|}{ Relative organ weight (\%) } \\
\hline Liver & $1.82^{\mathrm{b}}$ & $1.90^{\mathrm{ab}}$ & $2.02^{\mathrm{a}}$ & $1.96^{\mathrm{ab}}$ & 0.06 & 0.04 \\
\hline Spleen & 0.1 & 0.12 & 0.10 & 0.10 & 0.01 & 0.32 \\
\hline Bursa of Fabricius & 0.21 & 0.25 & 0.25 & 0.23 & 0.02 & 0.71 \\
\hline Breast muscle & 17.68 & 17.17 & 17.50 & 17.25 & 0.44 & 0.43 \\
\hline Abdominal fat & 0.77 & 0.84 & 0.87 & 0.73 & 0.07 & 0.15 \\
\hline Gizzard & 1.69 & 1.60 & 1.63 & 1.69 & 0.07 & 0.55 \\
\hline
\end{tabular}

${ }^{1} \mathrm{NC}=$ Basal diet; $\mathrm{PC}=\mathrm{NC}+0.5 \mathrm{~g} / \mathrm{kg}$ antibiotics (bacitracin methylene disalicylate); $\mathrm{BP} 1=\mathrm{NC}+0.25 \mathrm{~g} / \mathrm{kg}$ bacterophage; $\mathrm{BP} 2=\mathrm{NC}+0.5 \mathrm{~g} / \mathrm{kg}$ bacterophage.

${ }^{2}$ Standard error. ${ }^{a, b}$ Means in the same row with different superscripts differ $(\mathrm{p}<0.05)$. 
Table 6. The effects of bacterophage supplementation on excreta microflora in broilers ${ }^{1}$

\begin{tabular}{llllllr}
\hline Items, $\log _{10}$ CFU/g & CON & ANT & BP1 & BP2 & SE $^{2}$ & p-value \\
\hline Lactobacillus & $6.38^{\mathrm{b}}$ & $6.36^{\mathrm{b}}$ & $6.61^{\mathrm{ab}}$ & $6.72^{\mathrm{a}}$ & 0.11 & $<0.01$ \\
Escherichia coli & $6.75^{\mathrm{a}}$ & $6.32^{\mathrm{b}}$ & $6.38^{\mathrm{b}}$ & $6.28^{\mathrm{b}}$ & 0.13 & 0.01 \\
Salmonella & $3.24^{\mathrm{a}}$ & $2.56^{\mathrm{b}}$ & $2.79^{\mathrm{b}}$ & $2.64^{\mathrm{b}}$ & 0.16 & 0.03 \\
\hline${ }^{1} \mathrm{NC}=$ Basal diet; PC $=\mathrm{NC}+0.5 \mathrm{~g} / \mathrm{kg}$ antibiotics (bacitracin methylene \\
disalicylate); BP1 = NC+0.25 $\mathrm{g} / \mathrm{kg}$ bacterophage; BP2 = NC+0.5 g/kg \\
bacterophage. \\
${ }^{2}$ Standard error. \\
$\begin{array}{l}\text { a,b } \\
\text { Means in the same row with different superscripts differ }(\mathrm{p}<0.05) .\end{array}$
\end{tabular}

In our study we found that supplementation of bacteriophage can increase lactobacillus and decrease $E$. coli, and Salmonella concentration in excreta. Moreover, Lee and Harris (2001) had previously reported that Salmonella-specific lytic bacteriophage can be used as a potential method to reduce Salmonella in livestock. Atterbury et al. (2007) demonstrated that the bacteriophage supplementation could reduce cecal salmonella colonization of broiler chickens. Huff et al. (2004) also suggested that the inclusion of bacteriophage could reduce the $E$. coli colonization in broilers. Therefore, we hypothesized that the beneficial effect of the bacteriophages could be attributed to the improved microbial ecosystem in the broilers. Our results on the fecal microbial shedding also support this hypothesis, wherein the inclusion of bacteriophage led to a lower E. coli and Salmonella spp. concentrations compared with basal diet. Besides, it is interesting that a higher lactobacillus concentration was observed with the bacteriophage supplementation at the level of $0.5 \mathrm{~g} / \mathrm{kg}$, the reason for this difference is likely to be the reduced $E$. coli and Salmonella concentration, which provided a better ecosystem for the development of the lactobacillus.

The meat color of breast muscle was not affected by the treatment in current study. And we also found that the $\mathrm{pH}$ of breast muscle was not different among treatments. Generally, the meat color is closely associated with the meat $\mathrm{pH}$ (Fletcher, 1999). Therefore, the lack of response to meat color may be explained by the same $\mathrm{pH}$ value among treatments. This suggested that dietary supplementation of antibiotics or bacteriophage would not impact on meat color and $\mathrm{pH}$ value of breast muscle. Moreover, the inclusion of the bacteriophage increased the relative weight of liver to the body weight compared with the control group. No comparisons with other studies could be made because there have been no other studies conducted to evaluate the effects of bacteriphages on organ weight to date. The mechanism is also not clear. The liver is the largest metabolism and immune organ, so the development of liver in the earlier age (except unhealthy status) is beneficial for the chicks normal immunity function. As one of the largest immune organs of the animals, the gastrointestinal system and its associated lymphoid play and crucial role in the animals' immunological function (Insoft et al., 1996). It is hypothesized that bacteriophage can influence the population of gut intestinal microorganisms, which are necessary for the development of gut and liver immune system.

\section{CONCLUSIONS}

In conclusion, dietary supplementation of $0.5 \mathrm{~g} / \mathrm{kg}$ bacteriophage increase feed efficiency in starter phase and liver weight without effects on the breast muscle properties; also exert effect on inhibiting excreta pathogens shedding in broilers.

\section{REFERENCES}

AOAC. 2000. Official methods of analysis. 17th ed. Assoc. Off. Anal. Chem., Gaithersburg, MD, USA.

Atterbury, R. J., M. A. Van Bergen, F. Ortiz, M. A. Lovell, J. A. Harris, A. De Boer, J. A. Wagenaar, V. M. Allen and P. A. Barrow. 2007. Bacteriophage therapy to reduce Salmonella colonization of broiler chickens. Appl. Environ. Microbiol. 73:4543-4549.

Eeckhaut, V., F. Van Immerseel, J. Dewulf, F. Pasmans, F. Haesebrouck, R. Ducatelle, C. M. Courtin, J. A. Delcour and W. F. Broeckaert. 2008. Arabinoxylooligosaccharides from wheat bran inhibit Salmonella colonization in broiler chickens. Poult. Sci. 87:2329-2334.

Huff, W. E., G. R. Huff, N. C. Rath, J. M. Balog and A. M. Donoghue. 2002. Prevention of Escherichia coli infection in broiler chickens with a bacteriophage aerosol spray. Poult. Sci. 81:1486-1491.

Huff, W. E, G. R. Huff, N. C. Rath, J. M. Balog and A. M. Donoghue. 2004. Therapeutic efficacy of bacteriophage and Baytril (enrofloxacin) individually and in combination to treat colibacillosis in broilers. Poult. Sci. 83:1944-1947.

Insoft, R. M., I. R. Sanderson and W. A. Walker. 1996. Development of immune function in the intestine and its role in neonatal diseases. Pediatr. Clin. North Am. 43:551-571.

Lee, N. and D. L. Harris. 2001. The effect of bacteriophage treatment as a preharvest intervention strategy to reduce the rapid dissemination of Salmonella typhimurium in pigs. Proc. Am. Assoc. Swine Vet. American Association of Swine Veterinarians (AASV), Perry, IA. pp. 555-557.

NRC. 1994. Nutrient Requirements of Poultry. 9th rev. ed. Natl. Acad. Press, Washington, DC, USA.

SAS. 1996. SAS User's Guide: Statistics. Version 7.0. SAS Institute, Cary, NC, USA.

Twort, F. W. 1915. An investigation on the nature of the ultramicroscopic viruses. Lancet 186:1241-1243.

Toro, H., S. B. Price, A. S. McKee, F. J. Hoerr, J. Krehling, M. Perdue and L. Bauermeister. 2005. Use of bacteriophages in combination with competitive exclusion to reduce Salmonella from infected chickens. Avian Dis. 49:118-24.

Whichard, J. M., N. Sriranganathan and F. W. Pierson. 2003. Suppression of Salmonella growth by wild-type and largeplaque variants of bacteriophage Felix $\mathrm{O} 1$ in liquid culture and 
on chicken frankfurters. J. Food Prot. 66:220-225.

Williams, C. H., D. J. David, and O. Iismaa. 1962. The determination of chromic oxide in faeces samples by atomic absorption spectrophotometery. J. Agric. Sci. 59:381-385.
Zhao, P. Y., H. Y. Baek and I. H. Kim. 2012. Effects of bacteriophage supplementation on egg performance, egg quality, excreta microflora, and moisture content in laying hens. Asian-Aust. J. Anim. Sci. 25:1015-1020. 